DOI: 10.17707/AgricultForest.63.1.10

\author{
Svetlana SHEVCHENKO, \\ Valentina GORINA, Irina MITROFANOVA ${ }^{I}$
}

\title{
THE INFLUENCE OF VIRAL STATUS ON POLLEN CHARACTERISTICS OF SOME APRICOT CULTIVARS
}

\begin{abstract}
SUMMARY
Apricot is one of the leading temperate zone fruit-bearing crops and obtaining of its new cultivars with the highest economically-valuable features is an actual problem. The most effective method of new cultivars breeding is the hybridization. Considering the modern ecological situation, it is extremely important to create virus-free forms with high adaptive potential. During the monitoring of the viral diseases spread within apricot collection plots of Nikita Botanical Gardens - National Scientific Center (NBG-NSC)the analysis of mature pollen of 11 apricot cultivars was investigated. It was found out that studied cultivars are characterized by resistance to pathogens and affection by viruses. Two cultivars of NBG-NSC breeding (Krymsky Amur and Krymsky Medunec) and two introduced cultivars (Harcot and Markuleshti) demonstrated the difference to specified parameters. For example, the cultivar Krymsky Medunec is resistant to viral pathogens; its mature pollen has a large percentage of morphologically normal pollen grains characterized by high germination (up to $90 \%$ and $32 \%$, respectively). At the same time, cultivars Markuleshti and Harcot are strongly affected by Plum pox virus; their ripe pollen is morphologically normal, but low vital capacity level.. On $15 \%$ sucrose solution pollen grains of cultivar Harcot did not germinate, and cultivar Markuleshti had only $1 \%$ of germinating pollen grains. It should be noticed that complex application of biotechnological methods (chemotherapy and meristem culture), further using and propagation of virus-free explants in vitro let us get healthy plant material. Thus, the results suggest the potential for creating new perspective cultivars of apricot with preset characteristics for further breeding.
\end{abstract}

Keywords: apricot, cultivar, generative sphere, pollen grains, in vitro

\section{INTRODUCTION}

One of the most popular stone fruit crops is apricot Prunus armeniaca L., (syn. Armeniaca vulgaris Lam). Modern scientists distinguish from three to six possible places of apricot origin, the most likely of which is considered the area of the Tien Shan Mountains in China (Dalby, 2003; Folta, 2009). This culture has fruits with high taste quality, containing pectin substances, vitamins, sugars,

\footnotetext{
${ }^{1}$ Svetlana Shevchenko (corresponding author: shevchenko_nbs@mail.ru), Valentina Gorina, Irina Mitrofanova Nikita Botanical Gardens - National Scientific Center, Yalta, 298648, RUSSIA Paper presented at the $7^{\text {th }}$ International Scientific Agricultural Symposium "AGROSYM 2016". Notes: The authors declare that they have no conflicts of interest. Authorship Form signed online.
} 
organic acids, mineral salts, etc. The apricot fruits are used as a food for thousands years and they are cultivated in warm temperate regions of Europe, Central Asia, the Caucasus, Ukraine and southern regions of Russia. During the cultivation of apricot many varieties were derived, but there is still a need for new genotypes and the creation of new varieties with a complex of economicallyvaluable traits that would be adapted to growing conditions, as well as free from viral pathogens (Fideghelli and Della Strada, 2008; Gorina, 2014). It's known, that due to influence on plants biotic and abiotic stress, including viruses, there is a change of physiological-biochemical parameters, which cause violation of biochemical equilibrium and affect the anatomic-morphologic characteristics. Such morphological changes like rugosity, spotting and dwarfing are used for visual evaluation of the degree of the plant penetration of the plant and its viability as a whole (Grin et al., 1990; Mitrofanova et al., 2000). State of male gametophite is one of the most affordable and effective signs, that gives us information about the level of stressful influences of various factors on the plant and its viability (Ruguzov et al., 1979; Bessonova et al., 1997; Mitrofanova et al, 2000 a).The aim of our research is to monitor the spread of viral diseases in apricot collection plantations of the Nikita Botanical Gardens, as well as an assessment of morphophisiological state of the pollen grains of several cultivars of apricot with visual signs of defeat viruses and asymptomatic plants to determine the effects of a viral infection on their generative sphere.

\section{MATERIALS AND METHODS}

The objects of the research were 11 apricot cultivars: Krymsky Amur, Harcot, Krymsky Medunec, Dionis, Mamaia, Ananasnyi Zhiurupinsky, Krasnyi Vimpel, Magistr, Holovousy, Markuleshti, Harlayne. Pollen analysis was carried out on temporal preparations stained with aceto-orcein and the pollen germination were determinate by putting pollen in $15 \%$ sucrose solution (Pausheva, 1990). For invigoration the plant material complex of biotechnological methods were applied: chemotherapy and meristem culture. Material was put on modified nutrition media of Murashige \& Skoog (1962), and Gamborg \& Eveleigh (1968). For the chemotherapy during in vitro cultivation in the first phase in culturemedia $6 \mathrm{mg} / \mathrm{l}$ ribavirin was added. Seedlings with an extensive root system and shoots were planted in vessels with the ground to adapt to native conditions.

\section{RESULTS AND DISCUSSION}

As a monitoring result of viral diseases spread in apricot collection of Nikita Botanical Gardens (NBG-NSC) were determined visually clean individuals and specimens infected by virus pathogens were marked out for comparative analysis of the mature pollen. It was established that viruses on different cultivars causes different effects on morphophisiological characteristics of pollen grains (table 1,2). Despite the different temperature parameters in winter 2015 and 2016 (the average temperatures in December 2014 and January 
2015 were $+2.7^{\circ} \mathrm{C}$ and $+1.2^{\circ}$ Crespectively; in December $2015+2.5^{\circ} \mathrm{C}$ and $-0.3^{\circ} \mathrm{C}$ in January 2016), the reaction of almost all the study case varieties on contamination by viruses is identical. For example, in Krymsky Medunec, which is rather resistant to viral pathogens, the mature pollen has a large percentage of morphologically normal pollen grains characterized by high vitality. This cultivar, bred by the NBG scientists, is a medium size, fast-growing tree with a rounded crown, regular good yields $(160-180 \mathrm{~kg} / \mathrm{ha})$, resistance to stress low and high temperature of air (Figure 1).

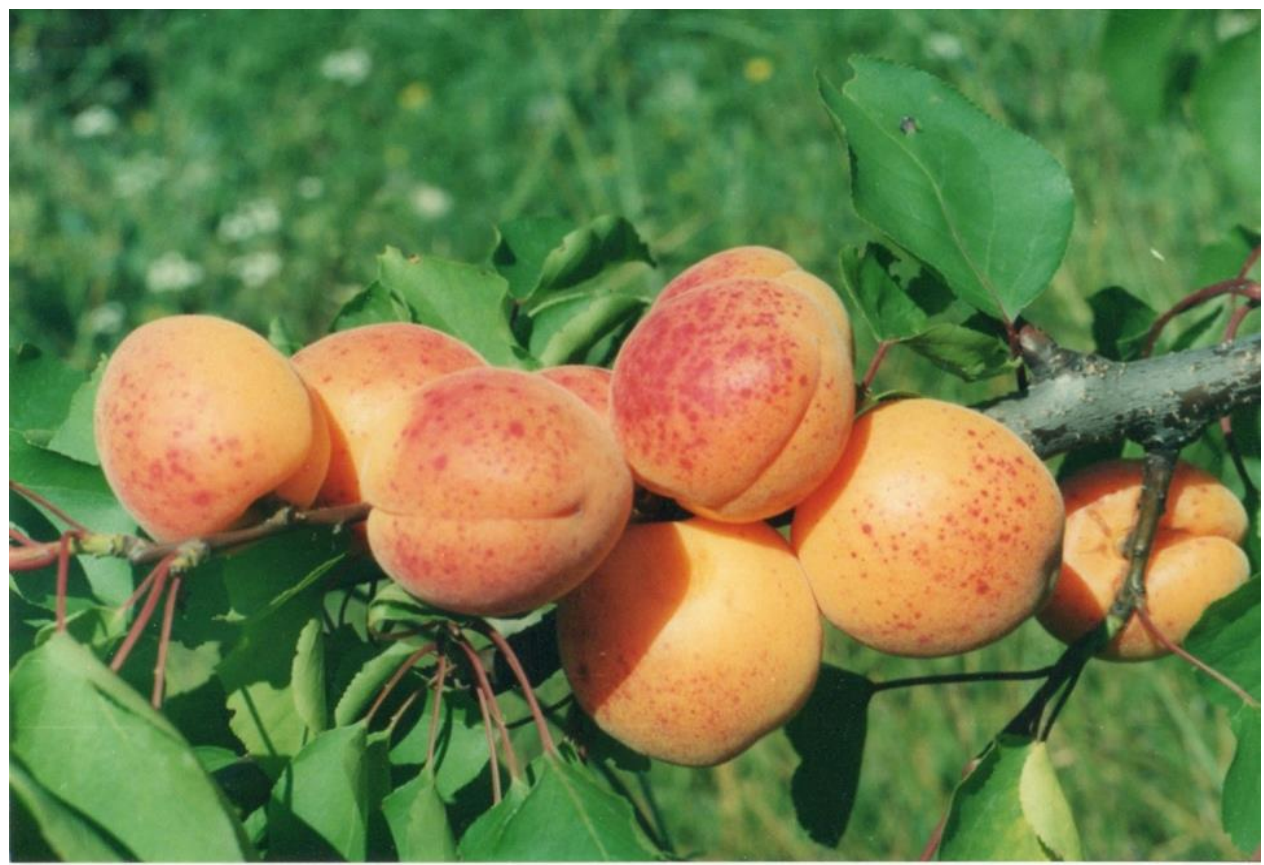

Figure 1. Shoot fragment with fruits of KrymskyMedunec cultivar

The cultivar Krymsky Amur was also quite resistant to viral pathogens, bred by NBG scientist. The tree is vigorous with spherical crown, quite high productivity (90-120 centners/hectare) and large fruits (until $90 \mathrm{~g}$ ) (Figure 2).

Mature pollen of the visually virus-affected individuals is characterized by high number of morphologically normal pollen grains.Pretty steady in aspect of viral pathogens was the cultivar Ananasnyi Zhiurupinskyas well with high content of morphophisiological normal pollen grains (Tables 1 and 2).

Cultivars Markuleshti and Harcot were strongly affected by Sharka virus. Mature pollen of Markuleshti has lots of morphologically normal pollen, but with low vitality. Majority part of pollen grains in cultivar Harcot is defective (table 2 ), and on $15 \%$ sucrose solution they do not germinate. Only $1 \%$ of germinating pollen grains was identified for cultivar Markuleshti. Cultivar Magistr has more than $10 \%$ of germinated pollen grains in the $15 \%$ solution in 6 hours after sowing. 


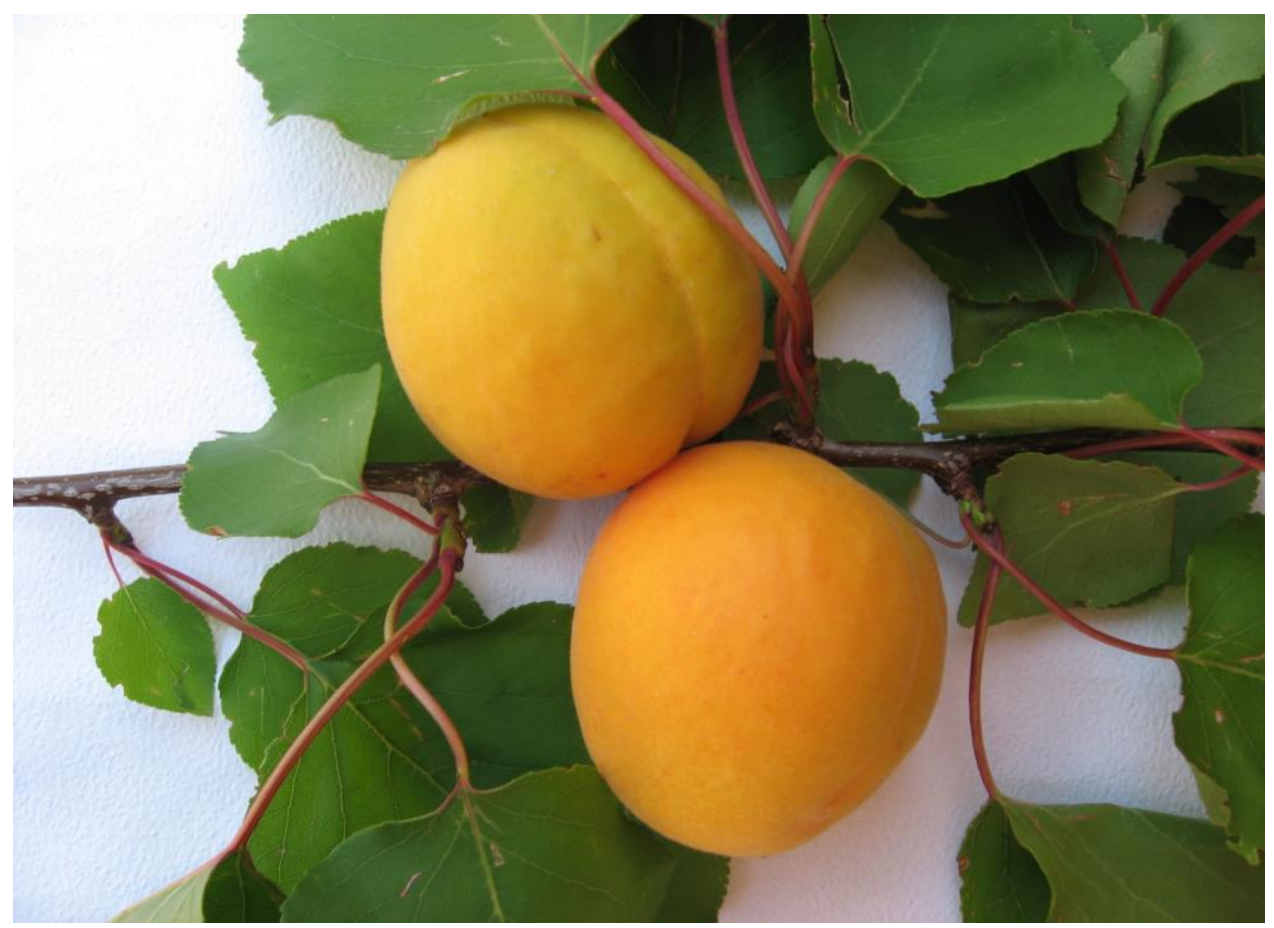

Figure 2. Fragment of shoot with fruits of Krymsky Amur cultivar

Complex use of biotechnological methods (chemotherapy and meristem culture in vitro) made it possible to introduce primary explants of cultivars Krymsky Amur on Gamborg \& Eveleigh medium and induce their development. Among study cases only cultivar Krymsky Amur possessed high morphogenetic potential (65-70\%). Ribavirin in culture medium was inhibited the growth and development of microshoots, and the number of developed meristems of cultivars KrymskyMedunec and Harcotdid not exceed 15\%. Further microcuttings of virus-free explants in vitro and their cultivation induced formation of adventive microshoots.

On the stage of root formation adding of NAA and IBA in concentrations of $1-1,5 \mathrm{mg} / \mathrm{l}$ to Murashige \& Skoog medium stimulated rhizogenesis in $57 \%$ microshoots of cultivar Krymsky Amur. Therefore, Sharka virus-affected plants of this cultivar were obtained in vitro. A similar effect was observed with ribavirin cultivation of undeveloped hybrid embryos of apricot (Shevchenko and Mitrofanova, 2015).

During of selection the parent forms and hybridization we allowed for not only pollen quality but also structure of the flower, because flowers with short pistil embryonic sacs are underdeveloped, the egg apparatus was not differentiated, what doesn't favor the effective fertilization. Study cultivars had different number of flowers with defective pistils. For example, more than $70 \%$ flowers of Markuleshti cultivar have undeveloped pistil, while for cultivar Krymsky Amurthis number until 30\% (Figure 3). 
Table 1. Characteristics of mature pollen of some apricot cultivars in April 2015

\begin{tabular}{|c|c|c|c|c|c|c|c|c|}
\hline \multirow[t]{2}{*}{ Cultivar } & \multicolumn{2}{|c|}{$\begin{array}{c}\text { Total number } \\
\text { of pollen grains }\end{array}$} & \multicolumn{2}{|c|}{$\begin{array}{c}\text { No of } \\
\text { morphologically } \\
\text { normal pollen } \\
\text { grains }\end{array}$} & \multicolumn{2}{|c|}{$\begin{array}{c}\text { No of } \\
\text { defective } \\
\text { pollen grains }\end{array}$} & \multicolumn{2}{|c|}{$\begin{array}{c}\text { Percentage of } \\
\text { defective pollen } \\
\text { grains }(\%)\end{array}$} \\
\hline & $1^{*}$ & $2^{*}$ & 1 & 2 & 1 & 2 & 1 & 2 \\
\hline $\begin{array}{c}\text { Ananasnyi } \\
\text { Zhiurupinsky }\end{array}$ & 1090 & - & 1000 & - & 90 & - & 8,025 & - \\
\hline Krasnyi Vimpel & 1000 & & 840 & & 160 & & 16,0 & \\
\hline Holovousy & - & 1420 & - & 1000 & - & 420 & - & 29,6 \\
\hline Mamaia & - & 1200 & - & 200 & - & 1000 & - & 83,3 \\
\hline Harlayne & - & 1200 & - & 630 & - & 570 & - & 47,5 \\
\hline Harcot & - & 1060 & - & 60 & - & 1000 & - & 94,3 \\
\hline Markuleshti & 1120 & - & 1000 & - & 120 & - & 10,7 & - \\
\hline Krymsky Amur & 1100 & - & 1000 & - & 100 & - & 9,1 & - \\
\hline $\begin{array}{l}\text { Krymsky } \\
\text { Medunec }\end{array}$ & - & 1320 & - & 1000 & - & 320 & - & 24,2 \\
\hline Dionis & - & 2400 & - & 1000 & - & 1400 & - & 58,3 \\
\hline Magistr & - & 1250 & - & 1000 & - & 250 & - & 20,0 \\
\hline
\end{tabular}

$1^{*}$ - visually clean apricot plants

$2^{*}$ - plants affected by viral pathogens

Table 2.Mature pollen characteristics of some apricot cultivars in March-April 2016

\begin{tabular}{|c|c|c|c|c|c|c|c|c|}
\hline Cultivar & \multicolumn{2}{|c|}{$\begin{array}{c}\text { Total } \\
\text { number of } \\
\text { pollen grains }\end{array}$} & \multicolumn{2}{c|}{$\begin{array}{c}\text { No of } \\
\text { morphologically } \\
\text { normal pollen } \\
\text { grains }\end{array}$} & \multicolumn{2}{c|}{$\begin{array}{c}\text { No of } \\
\text { defective } \\
\text { pollen } \\
\text { grains }\end{array}$} & \multicolumn{2}{c|}{$\begin{array}{c}\text { Percentage of } \\
\text { defective } \\
\text { pollen grains } \\
(\%)\end{array}$} \\
\hline & 1 & 2 & 1 & 2 & 1 & 2 & 1 & 2 \\
\hline $\begin{array}{c}\text { Ananasnyi } \\
\text { Zhiurupinsky }\end{array}$ & 1390 & 2940 & 1220 & 2500 & 170 & 440 & 12,2 & 15,0 \\
\hline $\begin{array}{c}\text { Krasnyi } \\
\text { Vimpel }\end{array}$ & 1340 & - & 1250 & - & 90 & - & 6,7 & - \\
\hline Holovousy & 1330 & 3790 & 970 & 2500 & 390 & 1290 & 29,3 & 34,0 \\
\hline Mamaia & 1280 & 2200 & 1160 & 210 & 120 & 1990 & 9,37 & 90,45 \\
\hline Harlayne & 1120 & 2040 & 930 & 960 & 190 & 1080 & 16,9 & 52,9 \\
\hline Harcot & 1200 & 1610 & 1050 & 80 & 150 & 1530 & 12,5 & 99,5 \\
\hline Markuleshti & 1270 & 2830 & 1180 & 2310 & 90 & 520 & 71 & 18,4 \\
\hline Krymsky Amur & 1080 & 1820 & 980 & 1620 & 100 & 200 & 9,26 & 11,0 \\
\hline $\begin{array}{c}\text { Krymsky } \\
\text { Medunec }\end{array}$ & 1230 & 4900 & 1100 & 4400 & 130 & 500 & 10,6 & 10,2 \\
\hline Dionis & 990 & 4090 & 520 & 1890 & 470 & 2200 & 47,5 & 53,8 \\
\hline Magistr & 1520 & 1840 & 1480 & 1520 & 40 & 320 & 2,6 & 17,4 \\
\hline
\end{tabular}

$1^{*}$ - visually clean apricot plants

$2^{*}$ - plants affected by viral pathogens 


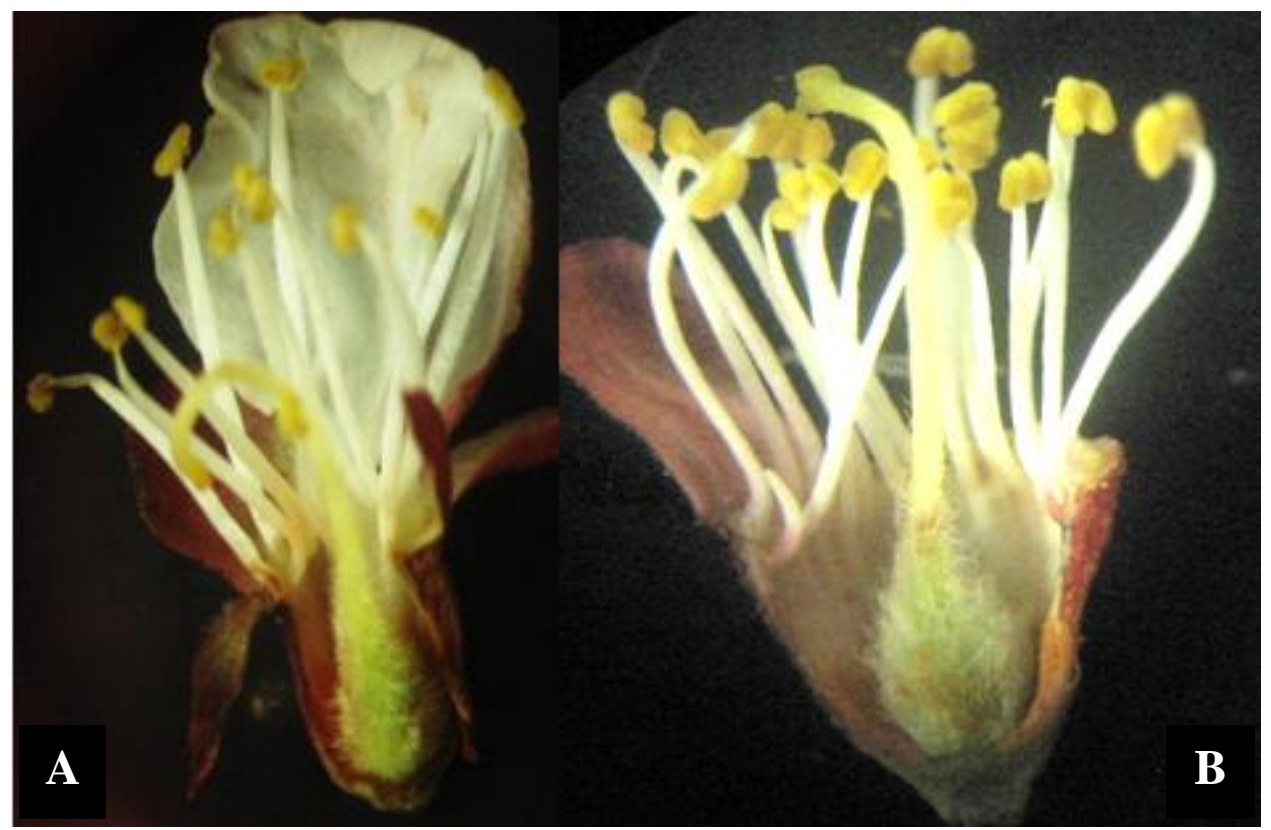

Figure 3. Fragments of Markuleshti cultivars flower (A) and Krymsky Amurflower (B)

\section{CONCLUSIONS}

Based on the research results we can conclude that the morphological and physiological characteristics of pollen depend not only on the genotype, but also on the stability of cultivars affected by viral pathogens. Cultivars Krymsky Amur, Krymsky Medunec, Magistr and Ananasnyi Zhiurupinsky we recommended to use as parent cultivars for creation of new genotypes, which are resistant to environmental stress factors. Application of complex biotechnological methods (chemotherapy and meristem culture in vitro) allows getting and multiplying invigorative valuable plant material. In general, to increase efficiency of breeding process requires complex approach that involves biological and phenological researches, the study of generative sphere, improvement of plant health, adaptation and reproduction of obtained valuable genotypes.

\section{ACKNOWLEDGMENT}

This study was funded by a research grant № 14-50-00079 of the Russian Science Foundation.

\section{REFERENCES}

Bessonova V.P., Fendûr L.M., Peresypkina T.N. (1997). Environmental pollution media on male fertility decorative flower crops. Bot. Zhurn. Vol. 82, No. 5. 38-44.

Gorina V.M. (2014). Scientific basis for the selection of apricot and plum for the Crimea and southern Ukraine.PhD Thesis, Michurinsk, 479p. 
Grin N., Staut U., Teylor D. (1990). Biology: in 3 volumes. Vol. 1. - M.: Mir. - 368 p.

Dalby A. (2003). Food in the ancient world from A to Z. P. 20.

Gamborg O.L., Eveleigh D.E. (1968). Culture method and detection of glucanases in suspension cultures of wheat and barley. Can. J. Biochem., 46, 5, 417-421.

Fideghelli C., Della Strada G. The breeding activity on apricot in the world from 1980 through today.ActaHorticulturae 862, 93-98.

Folta, K.M.(2009). Cenetics and Genomics of Rosaceae. Springer-Verlag. New-York.

Ruguzov I.A., Shevchenko, S.V., Molchanov E.F. (1979). Methodical recommendations for citoembryological analysis of plants to assess air pollution (in connection with the problem of environment) / (1979). Comp. Yalta. - $23 \mathrm{p}$.

Mitrofanova O., Lesnikova N., Mitrofanova I., Vogegov S. (2000a). Application of biotechnology method for obtaining the valuable cultivars of stone fruits. Horticulture and Vegetable Growing 19. 3. Part 1. 367-374.

Mitrofanova O.V., Slavgorodska-Kurpieva, L. MitrofanovaI.V., Lukicheva L.A. (2000) Diagnostics of viral diseases and biotechnological techniques for obtaining virusfree planting material stone fruit crops. -Yalta: Krympress. - 45 p.

Murashige T., Skoog F. (1962). A revised medium for rapid growth and bioassays with tobacco tissue cultures. Physiol. Plant., 15, 3,473-497.

Pausheva Z.P. (1990). Practicum by plant cytology. V. : Kolos. -283 p.

Shevchenko S., Mitrofanova I. (2015) Investigation of apricot reproductive structures, creation and propagation of new forms.Agriculture \& Forestry, Vol. 61, Issue $4: 161-167$. 